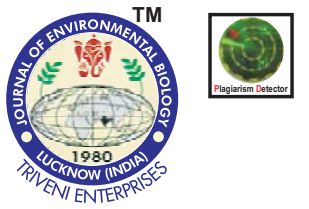

\title{
Studies on the effect of day time application of herbicide mesosulfuron- methyl on soil microbial communities of wheat rhizosphere
}

Authors Info

\author{
A. Singh ${ }^{1 *}$, M.L. Kewat \\ and S. Sondhia ${ }^{2}$ \\ ${ }^{1}$ Department of Agronomy, \\ Jawaharlal Nehru Krishi \\ Vishwa Vidyalaya, \\ Jabalpur-482 004, India \\ ${ }^{2}$ ICAR-Directorate of Weed \\ Research, Jabalpur-482 004, India
}

*Corresponding Author Email : ashasinghrajpoot@gmail.com

Key words

Mesosulfuron-methyl Microbial population Wheat rhizosphere

Publication Info

Paper received: 07.01 .2017

Revised received : 08.03.2017

Re-revised received: 16.07.2017 Accepted: 04.08.2017

\section{Abstract}

Aim : Mesosulfuron-methyl is one of the post emergence sulfonylurea herbicides and biotransformation is major process for its degradation. Persistence of mesosulfuron-methyl in soil mainly depends on temperature and microbial population. When herbicide is applied at different time of a day, it is exposed to different soil environmental factors. This interaction of mesosulfuron-methyl with soil environmental factors may affect microbial population differentially. Hence, the main objective of the study was to find how the day time application of mesosulfuron-methyl at different doses affects the microbial population of wheat rhizosphere.

Methodology : Five weed control treatments, comprising of three doses of mesosulfuronmethyl (10.0, 11.5 and $\left.12.0 \mathrm{~g} \mathrm{ha}^{-1}\right)$ including one hand weeding and weedy check as main plot treatments, were superimposed with three day times of herbicide application (8 a.m., 12 p.m. and 6 p.m.) as sub plot treatments and laidout in split plot design with four replications. Soil sample were collected at 5, 10, 30 and 80 days after herbicide application. The developed colonies were counted using serial dilution plate count technique and expressed as colony forming units (cfu) per gram dry soil.

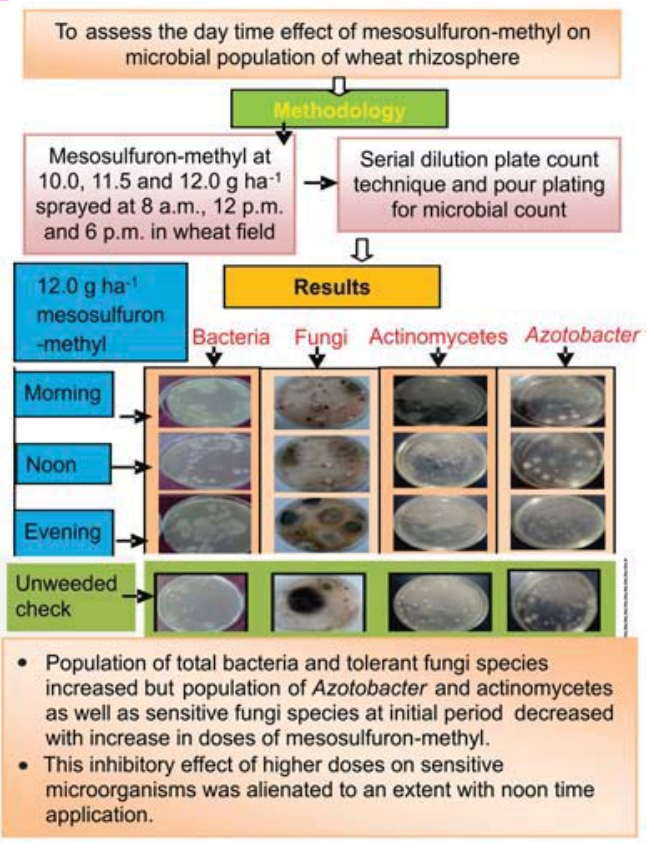

Results : Bacterial population was significantly (14.20 and $16.14 \%$ ) higher under $12 \mathrm{~g} \mathrm{ha}^{-1}$ mesosulfuron-methyl application over unweeded check at 10 and 30 days after, respectively. However, competition with dominant bacterial population and toxic effect of herbicide immediately after application inhibited fungal and actinomycete species. But with time, adapted fungal population was increased to 24.77 and $58.13 \%$ under $11.5 \mathrm{~g} \mathrm{ha}^{-1}$, and 28.77 and $73.40 \%$ under $12.0 \mathrm{~g}$ ha $^{-1}$ application at 30 and 80 days after application, respectively, over 10 days after application. While, the population of actinomycetes and Azotobactor was ever less under mesosulfuron-methyl in comparison to non-herbicidal treatments. However, fungal and actinomycetes population survived successfully in case of mesosulfuron application during noon hours even at higher doses due to less residue in soil.

Interpretation: Population of Azotobactor and actinomycetes (up to 80 days) as well as fungi (upto 10 days) was affected due to mesosulfuron doses except bacteria. Similarly, fungal and actinomycetes population was affected identically due to morning and evening application of mesosulfuron. On the contrary bacterial and Azotobactor population did not vary. 


\section{Introduction}

Crop protection plays a key role in sustaining the crop productivity against pests like weed, insect, disease and rodents. Among all these pests, weeds cause identical reduction in the productivity of irrigated wheat (Ryan et al., 2009; Smith et al., 2010). But these days, due to higher labourer wages for manual weeding in wheat, the farmers are relying completely on herbicides as these are cost effective. Mesosulfuron-methyl (Methyl2-[[[[(4,6 dimethoxy-2-pyrimidinyl) amino] carbonyl] amino] sulfonyl] -4- [(methylsulfonyl) amino] methyl] benzoate) is one of the post emergence sulfonylurea herbicides, which is mainly used for controlling grassy weeds and some broad leaf weeds in wheat by inhibiting acetolactate synthase enzyme (Yuan et al., 2013). However, when herbicide is applied to the field, it not only control target weeds, directly or indirectly reaches the soil and later subjected to various processes viz., sorption, degradation and transport from the site of application. It is important to note that the members of this group are highly persistent in soil and even at low concentration cause residual effect on succeeding or rotational crops after winter wheat (Walker and Brown, 1982; Singh et al., 2003; Sondhia et al., 2013, 2016). However, mesosulfuron-methyl exhibit very high to medium mobility, hence it is highly liable to leach to ground water or reach surface water by runoff and consequently, contaminate both surface and groundwater bodies. Hence, information on fates and behaviour of herbicide is most important aspect for maintaining the sustainable agriculture production system and healthy environment. There are two pathways for breakdown of sulfonylureas, first one is hydrolysis which occurs rapidly under acidic conditions but another is microbially mediated break down in neutral or alkaline soil (Brown and Cotterman, 1994). In general, these herbicides degraded in soil primarily by chemical hydrolysis and then microbial metabolism but some researcher illustrated the relative importance of microbial degradation (Ismail and Lee, 1995; Ye et al., 2003). While, the photolysis and volatilization are relatively minor processes for degradation of sulfonylurea group members in soil (Sondhia, 2008). Mesosulfuron-methyl is degraded in soil and water via hydrolysis and $\mathrm{O}$ - demethylation reactions and major metabolites (which represent to more than $10 \%$ of the applied radioactivity) of its degradation are mesosulfuron acid; 4,6-dimethoxypyrimidine-2yl-urea; 2-amino-4,6-dimethoxypyrimidine. The all transient intermediate metabolites are also degraded to final products viz., non-extractabled residues (59.2\%) and $\mathrm{CO}_{2}(32.1 \%)$ at day 120 (EFSA, 2016). Since, in case of mesosulfuron, biotransformation is the major pathway of degradation, hence its persistence varies with microbial population and temperature in non-sterile aerobic soil. According to EFSA (2008), with the decrease in temperature from $20^{\circ} \mathrm{C}$ to $10^{\circ} \mathrm{C}$, half life of mesosulfuron-methyl increased upto 154 from 49.1 days. Studies of Sebiomo et al. (2011) also revealed that some microorganisms are able to degrade herbicide, while others are adversely affected depending on the application rates and type of herbicide used. However, at recommended rate, herbicides have no short or long-term effect on microbial populations (Bollen, 1961). But injudicious use of herbicides to achieve higher weed control efficacy may also have ill effects on public health and environment. Whitcomb (1999) also reported that herbicides which inhibit acetolactate synthase enzyme, affect many species of higher plants as well as bacteria, fungi, yeasts and algae. Since photodegradation, photolysis and volatilization processes are not significant for mesosulfuron-methyl, hence instead of increasing its rate only, change in time of application during day hours (morning, noon and evening) could be taken into consideration so as to enhance activity of mesosulfuron-methyl against weeds even with lower dose. But when it applied at different time of the day, herbicide interact with different climatic factors (air temperature, relative humidity, light intensity, dew and wind velocity), edaphic factors (soil temperature and soil moisture) and plant morphology which are varied throughout the day, may not only have influence on the efficacy of herbicide but also affect the amount of herbicide going in the soil, sorption and rate of degradation. Sondhia et al. (2013) and Zain et al. (2013) reported that herbicides affect microbial growth, either positively or negatively; depending on chemicals (class and concentration), microbial species and environmental factors such as temperature, moisture and $\mathrm{pH}$ etc. Hence, interaction of different doses of mesosulfuron-methyl with day time applications may influence soil microbial population differently. However, information on how day time application of mesosulfuron-methyl at three rates affects the most important groups of soil microorganisms viz., bacteria, fungi, actinomycetes and Azotobactor in field condition, is not available in literature. Hence, keeping these facts in view, the present study was undertaken to find suitable time of day for mesosulfuron-methyl application and its suitable dose for recommendation, which have less or no adverse effect on microbial communities of wheat rhizosphere soil of Kymore Plateau and Satpura hills zone of Madhya Pradesh.

\section{Materials and Methods}

Experimental details : A field experiment was conducted during Rabi seasons of 2014-15 and 2015-16 at Product Testing Unit, Department of Agronomy, JNKVV, Jabalpur (M.P.) to assess the effect of day time application of mesosulfuron-methyl on microbial population of wheat rhizosphere. The soil of the experimental field was sandy clay loam in texture, neutral in reaction $(\mathrm{pH} \mathrm{7.0)}$, electrical conductivity $\left(0.33 \mathrm{dS} \mathrm{m}^{-1}\right)$, medium in organic carbon $(0.62 \%)$, available $\mathrm{N}\left(393 \mathrm{~kg} \mathrm{ha}^{-1}\right)$ and available $\mathrm{P}\left(17.44 \mathrm{~kg} \mathrm{ha}^{-1}\right)$ but high in available $\mathrm{K}\left(296 \mathrm{~kg} \mathrm{ha}^{-1}\right)$. Fifteen treatments comprising of three doses of mesosulfuron-methyl (10,11.5 and $12 \mathrm{~g} \mathrm{ha}^{-1}$ ) including one hand weeding (30 DAS) and unweeded check as main plot treatments and were superimposed with three day times of herbicide application ( 8 a.m., 12 p.m. and 6 p.m.) as sub plot treatments and laid out in a split plot design with four replications. Wheat variety GW 273 was sown in the experimental field with recommended package of practices. Half of nitrogen (60 $\left.\mathrm{kg} \mathrm{ha}^{-1}\right)$ and full quantity of $\mathrm{P}_{2} \mathrm{O}_{5}\left(60 \mathrm{~kg} \mathrm{ha}^{-1}\right)$ and $\mathrm{K}_{2} \mathrm{O}\left(40 \mathrm{~kg} \mathrm{~h}^{-1}\right)$ was applied as basal through urea, single super phosphate and muriate of potash. The remaining quantity of nitrogen was applied 
in the two splits (30 and 55 DAS). The herbicide was sprayed as post emergence using a spray volume of $500 \mathrm{I}$ ha ${ }^{-1}$ with a knapsack sprayer fitted with flat fan nozzle.

Enumeration of microorganisms : Soil sample were collected from $0-15 \mathrm{~cm}$ surface soil from all the plots at $5,10,30$ and 80 days after herbicide application during both the years. The soil samples were soaked into $90 \mathrm{ml}$ deionized water @ $10 \mathrm{~g}$, later this mixture was shaken for $10 \mathrm{~min}$ and kept for $5 \mathrm{~min}$. Thereafter, $1 \mathrm{ml}$ of the supernatant was diluted twice and incubated in diluted water at constant temperature of $30^{\circ} \mathrm{C}$. All samples were performed in triplicate, and were used for enumeration of microorganisms. The viable microbial counts were analyzed by standard technique of serial dilution and pour plating. Enumeration of bacteria and fungi was carried out in soil extract by Nutrient Agar medium (James, 1958) and Rose Bengal Agar medium (Parkinson et al., 1971) respectively. Kenknight's Agar medium (Wellingtonn and Toth, 1963) and Ashbys Mannitol Agar medium (Rao, 1977) were used for enumeration of actinomycetes and Azotobactor, respectively. After allowing for development of discrete microbial colonies during incubations period of $48 \mathrm{hrs}$ for bacteria, $48-72 \mathrm{hrs}$ for fungi, 7 days for actinomycetes and 5 days for Azotobacter, the colonies were counted and the number of viable bacteria, fungi actinomycetes and Azotobactor [expressed as colony forming units (cfu)] per gram dry weight of soil was estimated by taking into account soil dilutions.

Statistical analysis : The data obtained on microbial counts were tabulated and subjected to statistical analysis as per method of analysis of variance appropriate for split plot design as suggested by Snedecor and Cochron (1967). The influence of treatment was tested with $\mathrm{F}$ test values significant over the tabulated value, the differences between the treatments were further compared with critical difference at $5 \%$ level of probability.

\section{Results and Discussion}

It is evident from the data given in Table 1 that total bacterial population was minimum at 5 days after its application, which increased correspondingly with time being maximum at 80 days after its application under all the treatments, irrespective of doses of mesosulfuron-methyl and day time applications, suggesting that wheat rhizosphere is beneficial for the growth and reproduction of bacteria regardless of mesosulfuron-methyl doses and its application time. Similar view has been endorsed by Tamilarasi et al. (2008). The bacterial population at 5 days after application did not differ significantly in plots receiving mesosulfuron-methyl at different doses and was same to that of hand weeded and weedy check plots. But, at 10 and 30 days after its application numerically higher population was recorded when it was applied at highest dose (12 $\left.\mathrm{g} \mathrm{ha}^{-1}\right)$ in comparison to lower doses (10.0 and $\left.11.5 \mathrm{~g} \mathrm{ha}^{-1}\right)$. However, bacterial population was 1.47 and $3.32 \%$ higher at 30 days after application under lowest dose (10 $\left.\mathrm{g} \mathrm{ha}^{-1}\right)$ in comparison to hand weeding, which was further increased with corresponding increase in its dose of application being maximum (13.33 and $21.71 \%$ ) in plots receiving mesosulfuron-methyl at highest dose (12 $\left.\mathrm{g} \mathrm{ha}^{-1}\right)$ during 2014-15 and 2015-16, respectively. It may be attributed that bacteria relies on this herbicide as a source of nutrients and energy. Henceforth, the bacterial population was maximum under mesosulfuronmethyl at highest dose (12 g ha $\mathrm{a}^{-1}$ ). Ratcliff et al. (2006) also did not observe any change in microbial abundance in soil treated with glyphosate dose of $50 \mathrm{mg} \mathrm{kg}^{-1}$, but microbial counts increased in response to a 100-fold increase in herbicide dose. While at 80 days after application, the population was normalized and was almost in same range under all the treatments during 2014-15, but it was numerically higher in weedy check plots $\left(26.67 \times 10^{6}\right.$ cfu $\mathrm{g}^{-1}$ ) closely followed by hand weeding as compared to mesosulfuron-methyl application even at lowest dose (24.00 X $10^{6} \mathrm{cfu}^{-1}$ ) due to higher root biomass as well as more surface of

Table1 : Effect of day time application of mesosulfuron-methyl on bacterial population $\left(X 10^{6} \mathrm{cfu}^{-1}\right)$

\begin{tabular}{|c|c|c|c|c|c|c|c|c|}
\hline \multirow{3}{*}{ Treatment } & \multicolumn{7}{|c|}{ Exposure time (Days after application) } & \\
\hline & \multicolumn{4}{|c|}{ 2014-15 } & \multicolumn{4}{|c|}{ 2015-16 } \\
\hline & 5 & 10 & 30 & 80 & 5 & 10 & 30 & 80 \\
\hline \multicolumn{9}{|l|}{ Main plot (Herbicide dose) } \\
\hline Mesosulfuron-methyl $10 \mathrm{~g} \mathrm{ha}^{-1}$ & 17.17 & 18.67 & 22.83 & 23.33 & 23.67 & 25.00 & 26.17 & 23.00 \\
\hline Mesosulfuron-methyl $11.5 \mathrm{~g} \mathrm{ha}^{-1}$ & 17.00 & 21.17 & 23.83 & 23.83 & 23.00 & 27.33 & 28.67 & 24.67 \\
\hline Mesosulfuron-methyl $12 \mathrm{~g} \mathrm{ha}^{-1}$ & 17.00 & 22.50 & 25.50 & 23.67 & 22.00 & 28.50 & 30.83 & 23.83 \\
\hline Hand weeding (30 DAS) & 18.17 & 20.17 & 22.50 & 23.00 & 24.83 & 25.17 & 25.33 & 26.00 \\
\hline Unweeded check & 18.00 & 18.33 & 22.67 & 23.17 & 24.67 & 25.33 & 25.83 & 26.67 \\
\hline $\operatorname{LSD}(P=0.05)$ & NS & 0.80 & 1.87 & NS & NS & 2.04 & 2.67 & NS \\
\hline \multicolumn{9}{|l|}{ Sub-plot (day time of spray) } \\
\hline Morning (8 a.m.) & 17.60 & 20.20 & 23.30 & 23.60 & 23.50 & 26.70 & 27.70 & 25.00 \\
\hline Noon (12 p.m.) & 17.50 & 20.30 & 23.40 & 23.60 & 23.70 & 25.80 & 27.20 & 25.20 \\
\hline Evening (6 p.m.) & 17.30 & 20.00 & 23.50 & 23.00 & 23.40 & 26.30 & 27.20 & 23.70 \\
\hline $\operatorname{LSD}(P=0.05)$ & NS & NS & NS & NS & NS & NS & NS & NS \\
\hline
\end{tabular}


Table 2 : Effect of day time application of mesosulfuron-methyl on fungal population (X10 $\mathrm{cfu} \mathrm{g}^{-1}$ )

\begin{tabular}{|c|c|c|c|c|c|c|c|c|}
\hline \multirow{3}{*}{ Treatment } & \multicolumn{8}{|c|}{ Exposure time (Days after application) } \\
\hline & \multicolumn{4}{|c|}{ 2014-15 } & \multicolumn{4}{|c|}{ 2015-16 } \\
\hline & 5 & 10 & 30 & 80 & 5 & 10 & 30 & 80 \\
\hline \multicolumn{9}{|l|}{ Main plot (Herbicide dose) } \\
\hline Mesosulfuron-methyl $10 \mathrm{~g} \mathrm{ha}^{-1}$ & 17.67 & 17.33 & 20.83 & 22.67 & 23.00 & 22.33 & 25.67 & 31.17 \\
\hline Mesosulfuron-methyl $11.5 \mathrm{~g} \mathrm{ha}^{-1}$ & 15.33 & 16.50 & 21.33 & 25.67 & 22.17 & 22.50 & 27.33 & 37.00 \\
\hline Mesosulfuron-methyl $12 \mathrm{~g} \mathrm{ha}^{-1}$ & 15.00 & 16.83 & 22.17 & 27.50 & 21.00 & 22.00 & 27.83 & 39.83 \\
\hline Hand weeding (30 DAS) & 18.00 & 18.50 & 20.67 & 20.83 & 23.33 & 23.83 & 22.33 & 28.17 \\
\hline Unweeded check & 18.33 & 18.83 & 20.83 & 22.00 & 24.33 & 24.00 & 21.50 & 27.50 \\
\hline $\operatorname{LSD}(P=0.05)$ & NS & NS & NS & 3.09 & NS & NS & 2.35 & 3.87 \\
\hline \multicolumn{9}{|l|}{ Sub-plot (day time of spray) } \\
\hline Morning (8 a.m.) & 17.10 & 17.90 & 22.20 & 24.10 & 22.40 & 23.00 & 24.40 & 33.10 \\
\hline Noon (12 p.m.) & 17.80 & 18.50 & 20.50 & 23.60 & 23.80 & 23.30 & 25.80 & 33.00 \\
\hline Evening (6 p.m.) & 16.00 & 16.30 & 20.80 & 23.50 & 22.10 & 22.50 & 24.60 & 32.10 \\
\hline LSD $(P=0.05)$ & 1.14 & 1.93 & NS & NS & 1.23 & NS & NS & NS \\
\hline
\end{tabular}

Table 3 : Effect of day time application of mesosulfuron-methyl on actinomycetes population $\left(\mathrm{X} 10^{4} \mathrm{cfu} \mathrm{g}^{-1}\right)$

\begin{tabular}{|c|c|c|c|c|c|c|c|c|}
\hline \multirow{3}{*}{ Treatment } & \multicolumn{8}{|c|}{ Exposure time (Days after application) } \\
\hline & \multicolumn{4}{|c|}{ 2014-15 } & \multicolumn{4}{|c|}{ 2015-16 } \\
\hline & 5 & 10 & 30 & 80 & 5 & 10 & 30 & 80 \\
\hline \multicolumn{9}{|l|}{ Main plot (Herbicide dose) } \\
\hline Mesosulfuron-methyl $10 \mathrm{~g} \mathrm{ha}^{-1}$ & 24.17 & 26.17 & 33.33 & 39.83 & 33.33 & 34.00 & 36.33 & 36.83 \\
\hline Mesosulfuron-methyl $11.5 \mathrm{~g} \mathrm{ha}^{-1}$ & 23.67 & 24.67 & 33.00 & 38.00 & 31.33 & 32.00 & 36.33 & 35.67 \\
\hline Mesosulfuron-methyl $12 \mathrm{~g} \mathrm{ha}^{-1}$ & 22.00 & 21.00 & 32.17 & 35.83 & 30.83 & 31.50 & 36.00 & 35.83 \\
\hline Hand weeding (30 DAS) & 24.83 & 26.00 & 35.33 & 40.83 & 39.00 & 39.33 & 40.00 & 46.83 \\
\hline Unweeded check & 24.50 & 27.17 & 36.50 & 41.17 & 42.00 & 42.00 & 42.83 & 55.33 \\
\hline LSD $(P=0.05)$ & NS & 2.48 & 2.64 & 3.26 & 6.84 & 6.62 & 4.36 & 7.78 \\
\hline \multicolumn{9}{|l|}{ Sub-plot (day time of spray) } \\
\hline Morning (8 a.m.) & 23.70 & 24.90 & 34.50 & 39.40 & 35.40 & 35.70 & 38.60 & 42.30 \\
\hline Noon (12 p.m.) & 24.40 & 26.60 & 35.60 & 39.60 & 35.70 & 36.20 & 40.80 & 42.70 \\
\hline Evening (6 p.m.) & 23.40 & 23.50 & 32.10 & 38.40 & 34.80 & 35.40 & 37.00 & 40.90 \\
\hline $\operatorname{LSD}(P=0.05)$ & NS & 1.85 & 1.24 & NS & NS & NS & 2.12 & NS \\
\hline
\end{tabular}

soil is covered with plant material of wheat and weeds in case of weedy plots. This helps in maintaining the soil temperature and soil moisture even when air temperature rises upto $41.5^{\circ} \mathrm{C}$ during 2015-16 (Fig.1), which are more favourable for microbial growth in comparison to high soil temperature and over dried soil (Lovieno and Baath, 2008). While, day time application of mesosulfuron-methyl had no marked influence on the bacterial population during both the years, however, 80 days after application highest counts were found under mesosulfuron application during noon time.

The fungal population was significantly influenced by mesosulfuron-methyl doses at later period both the years of experimentation (Table 2). The fungi population at 5 and 10 days after application was numerically higher when mesosulfuron- methyl was applied at lowest dose $\left(10 \mathrm{~g} \mathrm{ha}^{-1}\right)$ but it decreased with the increase in doses of mesosulfuron-methyl being the minimum when it was applied at highest dose $\left(12 \mathrm{~g} \mathrm{ha}^{-1}\right)$ during both the years 2014-15 and 2015-16. Whereas population was maximum under weedy check closely followed by hand weeding. But reverse was true at 30 and 80 days after application in case of mesosulfuron-methyl applied at highest and lower doses, as mesosulfuron-methyl $12 \mathrm{~g} \mathrm{ha}^{-1}$ registered maximum fungal counts during both years. This is attributed to moderately toxic effect on fungi during early period but colonies recovered from toxic effect at 30 days after application. Studies of Sondhia et al. (2013) also indicated that at 0 day (2 hours after application), the concentration of pyrazosulfuron-ethyl was high, as it was not utilized by fungi immediately after application but fungal growth was increased with time and 


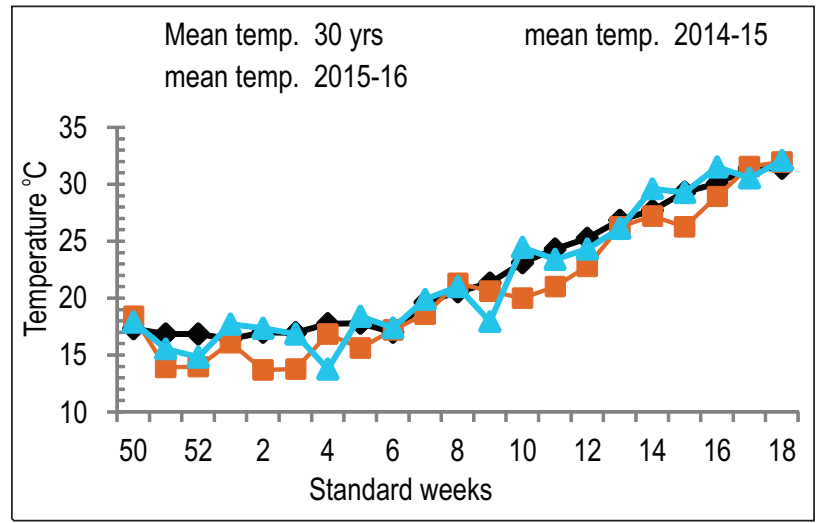

Fig.1 : Mean temperature during Rabi season 2014-15 and 2015-16

utilized pyrazosulfuron-ethyl successively. While at 30 days after application, degree of change in fungal counts was increased as the dose of herbicide increased during the both years. And fungal colony at 80 days after application was 7.59 and $13.35 \%$ higher with $10 \mathrm{~g} \mathrm{ha}^{-1}$, whereas it was 12.14 and $34.55 \%$ in plots receiving mesosulfuron-methyl at $11.5 \mathrm{~g} \mathrm{ha}^{-1}$ being 25.00 and $44.88 \%$ higher under highest dose (12 $\left.\mathrm{g} \mathrm{ha}^{-1}\right)$ over unweeded check during 2014-15 and 2015-16, respectively. These results showed that fungi are well adapted to mesosulfuron-methyl. Similar results have been reported by Ahtiainen et al. (2003). A stimulatory effect of increased dose of herbicides on fungal counts was observed by several workers viz., Sondhia et al. (2016) on penoxsulam at a dose of $25 \mathrm{~g} \mathrm{ha}^{-1}$, Crouzet et al. (2010) on mesotrione applied to soil at 0.45 to 45 $\mathrm{mg} \mathrm{kg}^{-1}$ and Zabaloy et al. (2010) on 2,4-dichlorophenoxyacetate applied in soil at 1 to $10 \mathrm{mg} \mathrm{kg}^{-1}$. While in case of day time applications, fungal population was significantly higher when mesosulfuron applied during noon at 5 and 10 days after application $\left(17.60 \times 10^{4}\right.$ and $\left.18.50 \times 10^{4} \mathrm{cfu} \mathrm{g}^{-1}\right)$ during first year and on $5^{\text {th }}$ days $\left(23.30 \times 10^{4} \mathrm{cfu} \mathrm{g}^{-1}\right)$ during second year of experimentation in comparison to morning and evening time application. Suggesting that noon time application of mesosulfuron-methyl did not have inhibitory effect on fungal population upto 10 and 5 days after application during first and second year, respectively. European Food Safety Authority (2008 and 2016) reported that temperature and microbial activity are major factors affecting the mesosulfuron-methyl degradation. However, the microbial activity is not started immediately after application of herbicide, then temperature becomes a major factor for its degradation. Henceforth, higher air temperature (20 and $22.6^{\circ} \mathrm{C}$ during 2014-15 and 2015-16, respectively) during noon time application caused faster degradation and left relatively lower residues of mesosulfuronmethyl in soil. As a consequence, the fungal population was higher during noon time application in comparison to morning as well as evening time application where air temperature was comparatively lower (ranges 9.6 to $18.6{ }^{\circ} \mathrm{C}$ ), which caused more accumulation of residues in soil and finally reduced the fungal population identically. However, day time application of mesosulfuron-methyl did not cause significant variation on the fungal population at 30 and 80 days after application during both the years.

Actinomycetes population was significantly influenced by doses of mesosulfuron-methyl at 10,30 and 80 days after application during 2014-15 and at all the time periods during 2015-16 in wheat rhizosphere (Table 3). During first year, actinomycetes population steadily increased with time when mesosulfuron-methyl was applied at lower doses (10.0 and $11.5 \mathrm{~g} \mathrm{ha}^{-1}$ ) but increase was not identical in case of highest dose $\left(12 \mathrm{~g}\right.$ ha $\left.{ }^{-1}\right)$. However, actinomycetes population at 5 days after application was statistically same under different doses of

Table 4 : Effect of day time application of mesosulfuron-methyl on Azotobactor population (X $\left.10^{4} \mathrm{cfu} \mathrm{g}^{-1}\right)$

\begin{tabular}{|c|c|c|c|c|c|c|c|c|}
\hline \multirow{3}{*}{ Treatment } & \multicolumn{7}{|c|}{ Exposure time (Days after application) } & \\
\hline & \multicolumn{4}{|c|}{ 2014-15 } & \multicolumn{4}{|c|}{ 2015-16 } \\
\hline & 5 & 10 & 30 & 80 & 5 & 10 & 30 & 80 \\
\hline \multicolumn{9}{|l|}{ Main plot (Herbicide dose) } \\
\hline Mesosulfuron-methyl $10 \mathrm{~g} \mathrm{ha}^{-1}$ & 10.33 & 11.00 & 12.00 & 10.33 & 10.67 & 13.00 & 18.33 & 13.00 \\
\hline Mesosulfuron-methyl $11.5 \mathrm{~g} \mathrm{ha}^{-1}$ & 10.17 & 10.67 & 12.33 & 8.83 & 10.33 & 13.00 & 18.17 & 12.50 \\
\hline Mesosulfuron-methyl $12 \mathrm{~g} \mathrm{ha}^{-1}$ & 10.00 & 10.50 & 12.33 & 7.50 & 9.67 & 10.67 & 17.33 & 9.00 \\
\hline Hand weeding (30 DAS) & 10.33 & 12.33 & 14.00 & 12.83 & 12.00 & 14.33 & 25.00 & 23.83 \\
\hline Unweeded check & 10.33 & 12.50 & 15.83 & 13.83 & 13.50 & 17.33 & 26.17 & 25.17 \\
\hline LSD $(P=0.05)$ & NS & NS & NS & 2.25 & NS & NS & 3.80 & 6.33 \\
\hline \multicolumn{9}{|l|}{ Sub-plot (day time of spray) } \\
\hline Morning (8 a.m.) & 10.20 & 11.10 & 13.30 & 10.70 & 10.90 & 13.30 & 20.90 & 16.10 \\
\hline Noon (12 p.m.) & 10.30 & 11.40 & 13.20 & 11.00 & 11.40 & 13.80 & 21.50 & 18.80 \\
\hline Evening (6 p.m.) & 10.20 & 11.70 & 13.40 & 10.30 & 11.40 & 13.90 & 20.60 & 17.00 \\
\hline $\operatorname{LSD}(P=0.05)$ & NS & NS & NS & NS & NS & NS & NS & NS \\
\hline
\end{tabular}


mesosulfuron-methyl to that of non herbicidal treatments. While at 10,30 and 80 days after application, actinomycetes population was identically decreased with corresponding increase in mesosulfuron-methyl doses and had 22.70, 11.86 and $12.97 \%$, respectively, lower population under highest dose in comparison to non herbicidal treatments viz., unweeded check, on account of stimulatory effect of rhizosphere on actinomycetes under non chemical environment. While, the effect of mesosulfuron-methyl on actinomycetes population was more pronounced during second year of experimentation and it differed significantly under different treatments at various time period. During 2015-16, the population of actinomycetes was minimum under $12 \mathrm{~g}$ ha ${ }^{-1}$ mesosulfuron-methyl application as it had $26.60,25.00,15.95$ and $35.24 \%$ lower population at 5 , 10,30 and 80 days after application, respectively, in comparison to weedy check which had maximum population followed by hand weeded plots at all time periods. However, the significant difference did not exist among herbicidal treatments. These effects attributed to better growth and development of actinomycetes under latter treatments on account of higher root biomass under non herbicidal environment, whereas reverse was true in case of herbicidal treatments. Sebiomo et al. (2011) reported maximum population of actinomycetes in control soil samples compared to herbicidal treated soil samples. While the effect of day time application of mesosulfuron-methyl on actinomycetes was noticeable at 10 and 30 days after application during 2014-15 and at 30 days after application during 2015-16. Among the day time applications, actinomycetes population was significantly higher at noon application over evening time, being statistically at par to morning time application. This may be due to less inhibitory effect of herbicide, on account of rapid degradation of mesosulfuron-methyl under relatively higher temperature when it was applied during noon hrs as well as there is less chances of runoff of herbicide due to absence of dew (Stewart et al., 2009), especially during winter season. However, day time application of mesosulfuron-methyl did not cause significant variation on the actinomycetes population 80 days after application during both the years because considerable amount of herbicide degraded as the time passes under the all day time applications upto 80 days.

The influence of mesosulfuron-methyl on Azotobactor is shown in Table 4. Unweeded check recorded highest population of Azotobactor over the all doses of mesosulfuron-methyl application being at par to hand weeding at all stages. It is clear that with the herbicide application, there was numerically same population of Azotobactor under all the treatments at 5 and 10 days after application, but gradually increased upto 30 days after application. This may be attributed to more reproduction of Azotobactor due to increased root biomass regardless of mesosulfuron-methyl application. However, 80 days after application the population was significantly 25.31 and $48.31 \%$ reduced when mesosulfuron-methyl was applied at $10 \mathrm{~g} \mathrm{ha}^{-1}$, 36.15 and $50.34 \%$ with $11.5 \mathrm{~g}$ ha $^{-1}$ and maximum reduction (45.77 and $64.24 \%$ ) was occurred at $12 \mathrm{~g} \mathrm{ha}^{-1}$ during both years 2014-15 and 2015-16, respectively, over weedy check which had more population of Azotobactor. This decline in Azotobactor population at later period was in line with the result of $\mathrm{He}$ et al. (2006) and Lone et al. (2014). Such a negative response of Azotobacter population could be attributed to competition between dominant population of fungi and actinomycetes at 80 days after application when large portion of mesosulfuron-methyl was degraded by bacteria and this lead to active growth of initial sensitive species of fungi and actinomycetes. However, day time application of mesosulfuron-methyl had no significant effect on Azotobacter population.

It is concluded that mesosulfuron-methyl application between 10.0 to $11.5 \mathrm{~g} \mathrm{ha}^{-1}$ during noon hours is safe as it had a little inhibitory effect on bacteria, Azotobacter including fungal and actinomycetes population of wheat rhizosphere, which are responsible for nitrogen mineralization, nitrogen fixation and biotransformation of organic matter in soil.

\section{Acknowledgments}

Authors greatly acknowledges Director Dr. A. R. Sharma, ICAR-Directorate of Weed Science (DWS) Jabalpur, India and Jawaharlal Nehru Krishi Vishwa Vidyalaya, Jabalpur (M.P.) India for providing necessary facilities to conduct this research work.

\section{References}

Ahtiainen, J.H., P. Vanhala and A. Myllymaki: Effects of different plant protection programs on soil microbes. Ecotox. Environ. Safe., 54, 56-64 (2003).

Bollen, W.B.: Interaction between pesticides and soil microorganisms. Annu. Rev. Microbiol., 15,69-92 (1961).

Brown, H.M. and J.C. Cotterman: Recent advances in sulfonylurea herbicides. Chem. Plant Prot., 10, 47-81 (1994).

Crouzet, O., I. Batisson, P. Besse-Hoggan, F. Bonnemoy, C. Bardot, F. Poly, J. Bohatier and C. Mallet: Response of soil microbial communities to the herbicidemesotrione: A dose-effect microcosmapproach. Soil Biol. Biochem., 42,193-202 (2010).

EFSA (European Food Safety Authority): Opinion on a request from EFSA related to the default $\mathrm{Q} 10$ value used to describe the temperature effect on transformation rates of pesticides in soil. EFSA J., 6,1,622,32 (2008).

EFSA(European Food Safety Authority): Peer review of the pesticide risk assessment of the active substance mesosulfuron (variant evaluated mesosulfuron-methyl). EFSA J., 14,10,4584 (2016).

He, Y.H., D.S. Shen, C.R. Fang, R. He and Y.M. Zhu: Effects of metsulfuron-methyl on the microbial population and enzyme activities in wheat rhizosphere soil. J. Environ. Sci. Heth. B., 41,3,269-84 (2006).

Ismail, B.S. and H.J. Lee: Persistence of metsulfuron-methyl in two soils. J. Environ. Sci. Hlth., 30,485-497 (1995).

James, N.: Soil extract in soil microbiology. Can. J. Microbiol., 4,363-370 (1958).

Lone, A.H., K.P. Raverkar and N. Pareek : In-vitro effects of herbicides on soil microbial communities. Bioscan, 9, 11-16 (2014).

Lovieno, P. and E. Baath: Effect of drying and rewetting on bacterial growth rates in soil. FEMS Microbiol Ecol., 65, 3,400-7 (2008).

Parkinson, D., T.R.G. Gray and S.T. Williams: Methods for studying 
ecology of soil microorganisms. IBP Hand Book 19, Blackwells Science Publication Limited, Oxford (1971).

Rao, S.: Soil Microorganisms and Plant Growth. Oxford and IHB Publishing Co., India (1977).

Ratcliff, A.W., M.D. Busse and C.J. Shestak: Changes in microbial community structure following herbicide (glyphosate) addition to forest soils. Appl. Soil Ecol., 34,114-124 (2006).

Ryan, M.R., R.G. Smith and D.A. Mortensen: Weed crop competition relationships differ between organic and conventional cropping systems. Weed Res., 49,572-580 (2009).

Sebiomo, A., V.W. Ogundero and S.A. Bankole: Effect of four herbicides on microbial population, soil organic matter and dehydrogenase activity. Afr. J. Biotechnol., 10, 770-778 (2011).

Singh, G., V.P. Singh and M. Singh: Studies on the effect of mesosulfuron and iodosulfuron on weeds in wheat, their compatibility with other chemicals and residual effects on succeeding crops. Indian J. Agron., 35,173-178 (2003).

Smith, R.G., D.A. Mortensen and M.R. Ryan: A new hypothesis for the functional role of diversity in mediating resource pools and weedcrop competition in agro-ecosystems. Weed Res., 50,37-48 (2010).

Snedecor, G.W. and W.G. Cochram: Statistical Methods. Oxford and IBH Publication, 6 $6^{\text {th }}$ Edn., pp.325-330 (1967).

Sondhia, S., S. Rajpoot and R.K. Varma: Biodegradation of the herbicide penoxsulam (triazolopyrimidine sulphonamide) by fungal strains of Aspergillus in soil. Appl. Soil Ecol., 105,196-206 (2016).

Sondhia, S., U. Waseem and R.K. Varma: Fungal degradation of an acetolactate synthase (ALS) inhibitor pyrazosulfuron-ethyl in soil. Chemosphere, 93,2140-2147 (2013).

Sondhia, S.: Persistence of metsulfuron-methyl in wheat crop and soil.
Environ. Monit. Assess., 147,463-469 (2008).

Stewart, C.L., R.E. Nurse and P.H. Sikkema: Time of day impacts post emergence weed control in corn. Weed Tech., 23,3,346-355 (2009).

Tamilarasi, S., K. Nanthakumar, K. Karthikeyan and P. Lakshmanaperumalsamy : Diversity of root associated microorganisms of selected medicinal plants and influence of rhizomicroorganisms on the antimicrobial property of Coriandrum sativum. J. Env. Biol., 29,1,127-134 (2008).

Walker, A. and P.A. Brown: Crop response to low doses of pendimethalin, napropamide, metazachlor and chlorsulfuron in soil. In: Proceedings of British Crop Protection Conference on Weeds, pp.141-147 (1982).

Wellingtonn, E.M.H. and I.K. Toth : Microbiology and biochemical properties. University of Warwick (1963).

Whitcomb, C.E.: An introduction to ALS-inhibiting herbicides. Toxicol. Ind. Hlth., 15,1-2 (1999).

Ye, Q., J. Sun and J. Wu: Causes of phytotoxicity of metsulfuron-methyl bound residues in soil. Environ Pollut., 126,417-423 (2003).

Yuan, X., P. Guo, X. Qi, N. Ning, H. Wang, H. Wang, X. Wang and Y. Yang: Safety of herbicide Sigma Broad on Radix isatidis (Isatis indigotica Fort.) seedlings and their photosynthetic physiological responses. Pestic. Biochem. Physiol., 106,45-50 (2013).

Zabaloy, M.C., J.L. Garland and M.A. Gomey: Assessment of the impact of 2,4-dichlorophenoxyacetic acid (2,4-D) on indigenous herbicide degrading bacteria and microbial community function in an agricultural soil. Appl. Soil Ecol., 46,240-246 (2010).

Zain, N.M.M., R.B. Mohamad, K. Sijam, M.M. Morshed and Y. Awang: Effects of selected herbicides on soil microbial populations in oil palm plantation of Malaysia: A microcosm experiment. Afr. J. Microbiol. Res., 7, 367-374 (2013). 